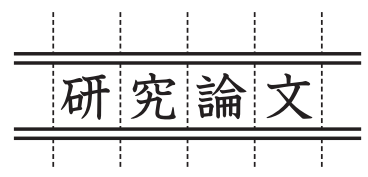

\title{
ガス切断中のドロス形成過程の三次元粒子法シミュレーション
}

\section{Dross Formation Process During Gas Cutting Using Three-Dimensional Particle Simulation}

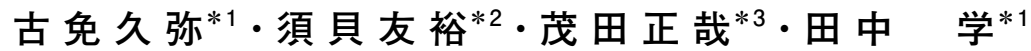 \\ 加藤 隆*2 ・北村 祐一郎*4 ・佐 藤 豊 幸*5
}

Hisaya KOMEN, Tomohiro SUGAI, Masaya SHIGETA, Manabu TANAKA, Takashi KATO, Yuichiro KITAMURA and Toyoyuki SATO

(Received 25 June 2021, Accepted 16 August 2021)

\begin{abstract}
A molten metal behavior on the underside of a workpiece in the gas cutting process was observed by a high-speed camera to clarify the effects of preheating gas and cutting speed on the behavior. Moreover, the molten metal behavior was modeled using a particle method. As a result, the molten metal behavior and the dross detachability were different for each preheating gas when the cutting speed was set to be $150 \mathrm{~mm} / \mathrm{min}$. From computational results, it was clarified that the molten metal showed different behavior because the cutting groove shape was different for each heat source. When hydrogen gas was used as the preheating gas, the molten metal indicated similar behavior regardless of increase of the cutting speed. However, it became hard to remove the dross from the underside of the workpiece. In addition, computational results showed that the average oxidation ratio of the dross surface which was jointed to the underside of the workpiece was different for each cutting condition. From these tendencies of the oxidation ratio and dross detachability, it was suggested that the oxidation ratio of the dross surface was one of factors to determine the dross detachability.
\end{abstract}

Key Words: Gas Cutting, Dross, Oxidation Heat, High-speed Camera, Particle Method

\section{1. 緒 言}

ガス切断は熱切断プロセスの 1 種であり、その熱源には ガス火炎が用いられる。この切断プロセスでは、水素ガス や液化プロパンガス (LPG: Liquefied Petroleum Gas) を使用 した予熱炎を用いて、被切断材料である鋼材の表面を高温 に熱する。そして赤熱した箇所に酸素ガスを吹き付け、鋼 材の酸化反応熱で鋼材自身を溶融し、溶融した金属を吹き 飛ばして溝を形成することで切断を達成する。このように 鋼材自身の酸化熱が切断部を溶融する熱エネルギーとなる ことがこの切断プロセスの特徴であり ${ }^{1)}$ 、例えば次式のよ うな酸化反応熱 ${ }^{2)}$ が生じる。

$$
\begin{gathered}
\mathrm{Fe}+\frac{1}{2} \mathrm{O}_{2}=\mathrm{FeO}+64.0 \mathrm{kcal} \\
2 \mathrm{Fe}+\frac{3}{2} \mathrm{O}_{2}=\mathrm{Fe}_{2} \mathrm{O}_{3}+190.7 \mathrm{kcal} \\
3 \mathrm{Fe}+2 \mathrm{O}_{2}=\mathrm{Fe}_{3} \mathrm{O}_{4}+266.9 \mathrm{kcal}
\end{gathered}
$$

これらの酸化反応が被切断材料の上部から下部の広い範囲
で生じることで、被切断材料は加熱され溶融するため、ガス 切断はプラズマ切断やレーザ切断等の他の切断プロセスが 切断可能な鋼材よりも厚い鋼材の切断を可能としている。

このガス切断を対象とした先行研究として、水津と安田 は楔形の試験片を用いて切断試験を行い、火口入口の酸素 圧力と火口口径から切断酸素流量を算出する実験式を導い た ${ }^{3)}$ 。また火口口径と切断速度から切断可能な最大板厚を 推定する実験式も考案し、これらを組み合わせることで切 断効率を算出する実験式を示した。続報では被切断材料で ある鋼の初期温度が切断効率に及ぼす影響を明らかにする ため、室温の他 400、700、1,000 C に予熱し、これらの初期 温度が切断効率に及ぼす影響を調査した ${ }^{4)}$ 。その結果、予 熱した条件はいずれも室温に比べて限界切断速度が大きく なった。さらに最大板厚と切断条件の関係および最大切断 効率と切断条件についての実験式も提案した ${ }^{4)}$ 。

寺崎らは予熱炎による熱量および切断による熱量を実験 により検討した。他方、熱伝導理論式によって予熱炎から 被切断材料に与えられる熱量のモデル化を行った ${ }^{5)}$ 。その

* 1 大阪大学接合科学研究所 ( $\overline{7}$ 567-0047 大阪府茨木市美穂ヶ丘 11-1)

Joining and Welding Research Institute, Osaka University (11-1, Mihogaoka, Ibaraki, Osaka 567-0047, Japan)

* 2 大陽日酸株式会社 山梨研究所（－ 408-0015 山梨県北杜市高根町下黒澤 3054-3）

Yamanashi Laboratories, Taiyo Nippon Sanso Corporation（3054-3, Shimokurosawa, Takane-cho, Hokuto, Yamanashi 408-0015, Japan)

* 3 東北大学大学院工学研究科（９ 980-8579 宮城県仙台市青葉区荒巻字青葉 6-6-01）

Graduate School of Engineering, Tohoku University（6-6-01 Aoba, Aramaki, Aoba-ku, Sendai, Miyagi 980-8579, Japan)

* 4 大陽日酸株式会社 デジタルソリューションセンター（１１42-0062 東京都品川区小山 1-3-26）

Digital Solution Center, Taiyo Nippon Sanso Corporation (1-3-26 Koyama, Shinagawa-ku, Tokyo 142-8558, Japan)

* 5 大陽日酸株式会社 プラントエンジニアリングセンター（† 210-0861 神奈川県川崎市川崎区小島町 6-2）

Plant Engineering Center, Taiyo Nippon Sanso Corporation（6-2 Kojima-cho Kawasaki-ku, Kawasaki, Kanagawa 210-0861, Japan） 
結果、異なる切断速度を設定しても予熱炎による単位時間 あたりの入熱量はほぼ一定であることを明らかにした。ま た寺崎らが行った実験の範囲内では、予熱炎の熱量分布は 火口先端の半径を基準にしたガウス分布によって概ね説明

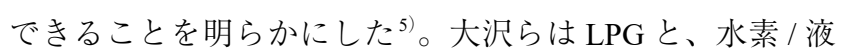
化プロパン (LP: Liquefied Petroleum) の混合ガスの 2 種類を 対象とし、予熱ガス火炎の伝熱特性の違いが予熱入熱や燃 焼入熱に及ぼす影響を、実験と数值計算によって定量的に 評価することを試みた。その結果、同じ板厚で比較すると 水素/LPの混合ガスを用いた場合の最高切断速度は、LPG を用いた場合よりも大きくなった ${ }^{6)}$ 。谷口は水素ガス切断 システムを開発し、水素ガスを用いてガス切断を行った方 が一般的な LPG を用いて行った場合に比べて歪みを抑えら れることや、高速で切断可能であったことを報告した7)。

このように切断の効率や予熱炎の入熱に関する研究はな されているものの、ガス切断時に被切断材料裏面から流れ 落ちる溶融金属の挙動を詳細に調査した研究例は見当たら ない。この溶融金属は切断中に切断溝を流れ、被切断材料 裏面に付着した後そのまま凝固することによってドロスを 形成する。ドロスは切断後に被切断材料董面から剥離する 必要があるが、切断の条件によってその剥離性が異なるこ とが経験的にわかっている。そのため切断条件次第ではド ロスの剥離が困難になり、切断後にドロスを剥離する工程 が増えることで生産効率の低下を招いている。これらの問 題を解決し、より効率的な切断を達成するためには、切断 後のドロスが剥離しやすいような切断条件の選定やそのメ カニズムの解明が必要である。

ガス切断においては今村らが酸化鉄を用いたペーストを 作製し、このペーストを被切断材料裏面に設置することで 被切断材料裏面へのドロスの固着を抑制することに成功し た ${ }^{8)}$ 。そして固着したドロスも容易に剥離することができた と報告した。他の切断プロセスにおいては、例えばYilbas と Aleem は Lump parameter 解析を用いて炭酸ガスレーザ切断中 の被切断材料の溶融深さや、飛散するドロスの直径をモデル 化した9)。このモデルを用いたシミュレーションによって、 飛散するドロスの直径はアシストガスの流速の低下やレー ザ出力の増加に伴って大きくなることが明らかとなり、これ らの傾向は実験とよく一致していた。また切断中に $100 \mu \mathrm{m}$ オーダーの厚みの液相が生じ、その液相の厚みはレーザ出力 の強度の影響を強く受けることを明らかにした。Nemchinsky はプラズマアーク切断中の切断速度に着目し、正常な切断が 可能な最低速度を数学モデルから求めた ${ }^{10)}$ 。このモデルを 用いた解析により、切断速度から求まる Weber 数がある值 に達することで、ドロスが発生するモードとドロスフリー のモードの遷移が生じることを示唆した。

このように、各熱切断プロセスにおけるドロス発生の抑 制やドロスと切断条件の関係についての調査はされている ものの、ガス切断プロセス中に被切断材料喠面に固着する ドロスの形成過程については明らかになっていない。より
高能率なガス切断プロセスの達成のためには、高速で切断 でき、切断後のドロスの剥離も容易であるような切断条件 の選定が必要である。しかしながらそのためには、まずは ガス切断プロセスで設定される切断条件が被切断材料裏面 のドロスの形成過程やその剥離性に及ぼす影響を明らかに しなければならない。

そこで本研究では、高速度ビデオカメラを用いた実験観 察を行うことで切断速度やガス種の違いによる溶融金属の 流動を調査すると共に、切断後にドロスを剥離することで その剥離性の違いを定性的に評価する。また、粒子法の 1 種である非压縮性 SPH (: Smoothed Particle Hydrodynamics) 法によってガス切断中の被切断材料の溶融現象や流動現象 のモデル化を行い、実験観察が困難な切断溝内の溶融金属 の流動現象をシミュレートする。そしてこれらの実験観察 や数值計算によって得られた知見から、切断速度やガス種 の違いが被切断材料裏面におけるドロスの形成やその剥離 性に及ぼす影響について明らかにすることを目的とする。

\section{2. 実験方法}

Fig. 1 に本研究で用いた実験装置の模式図を示す。実験 には切断方向の長さである板幅が $220 \mathrm{~mm}$ 、板厚が $250 \mathrm{~mm}$ の極低炭素鋼を被切断材料として使用し、その端部を直径 $20 \mathrm{~mm}$ のノズルを有するガス切断トーチの先端に形成した 予熱炎よって切断前に予熱した。そして予熱後にガス切断 トーチを切断速度 150 または $290 \mathrm{~mm} / \mathrm{min} て ゙$ 移動させるこ とで、被切断材料の切断を行った。高速度ビデオカメラは 被切断材料董面を撮影しており、準定常な状態になったと 考えられる切断終盤に、被切断材料の裏面を流れ落ちる溶 融金属の流動を記録した。このときの撮影速度は $2,000 \mathrm{fps}$ 、 露光時間は $200 \mu \mathrm{s}$ と設定した。なお、実験結果と計算結果 の切断方向を揃えるため、撮影後の映像は左右反転させた。 その他の実験条件を Table 1 に示す。切断後のドロスはケ

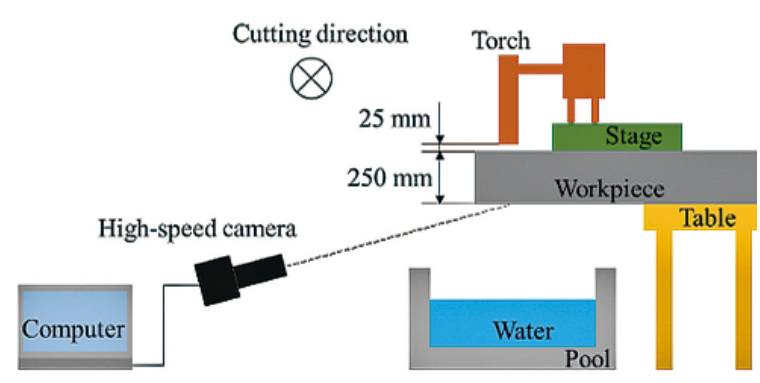

Fig. 1 Schematic illustration of experimental setup.

Table 1 Other experimental conditions.

\begin{tabular}{lcc}
\hline Preheating gas & LPG & Hydrogen gas \\
Preheating gas flow rate & $40 \mathrm{~L} / \mathrm{min}$ & $155 \mathrm{~L} / \mathrm{min}$ \\
Preheating oxygen gas flow rate & $100 \mathrm{~L} / \mathrm{min}$ & $84 \mathrm{~L} / \mathrm{min}$ \\
Cutting gas & \multicolumn{2}{c}{ Oxygen } \\
Cutting gas flow rate & $1,000 \mathrm{~L} / \mathrm{min}$ \\
\hline
\end{tabular}


レンを用いて人力で剥離を試み、その剥離性を確認した。

\section{3. 計算手法}

\section{1 支配方程式}

本研究では計算手法として、粒子法の 1 種である非圧縮性 SPH 法を用いる。粒子法は大変形や相変化を伴う流体の挙動 のシミュレーションに適しており、非圧縮性 SPH 法はティ グ溶接中の溶融池形成 ${ }^{11)}, 12$ 、ミグ溶接中の溶滴移行 ${ }^{13)}$ および 溶融池形成 ${ }^{14)}$ 15)、サブマージアーク溶接中の溶融池形成 ${ }^{16), 17)}$

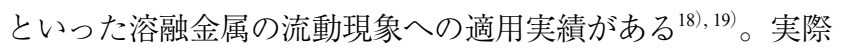
のガス切断では厚板を被切断材料としているが、切断中に 形成されるドロスの厚みは数 $\mathrm{mm}$ から数十 $\mathrm{mm}$ である。し たがって、その形成過程を十分な粒子解像度でシミュレー トするためにはドロスの厚みよりも細かい粒子径を選択す る必要があり、本計算では粒子径を $0.1 \mathrm{~mm}$ と設定している。 しかしながら、この粒子によって実験で用いたような厚さ $250 \mathrm{~mm}$ の被切断材料を構成すると膨大な粒子数が必要と なり、莫大な計算時間がかかる。そこで本計算では被切断 材料および熱源の寸法を実験よりも小さく設定し、異なる 切断速度や異なる熱源に対する溶融金属の流動について定 性的なシミュレーションを試みる。

任意の位置 $\vec{r}_{i}=\left(x_{i}, y_{i}, z_{i}\right)$ での溶融金属粒子 $i$ の速度べクト ル $\vec{u}_{i}$ は Navier-Stokes 方程式を SPH 法の離散化手法によっ て離散化し、外力を加えた次式で求められる。

$$
\begin{aligned}
\frac{D \vec{u}_{i}}{D t} & =-\sum_{j} m_{j}\left(\frac{p_{i}}{\rho_{i}^{2}}+\frac{p_{j}}{\rho_{j}^{2}}\right) \nabla_{i} W_{i j} \\
& +v \sum_{j} m_{j} \frac{\rho_{i}+\rho_{j}}{\rho_{i} \rho_{j}\left|\vec{r}_{i j}\right|}\left(\vec{u}_{i}-\vec{u}_{j}\right) \frac{\partial W_{i j}}{\partial r_{i}}+\vec{g}+\frac{\vec{F}_{i}^{\mathrm{L}}+\vec{F}_{i}^{\mathrm{LS}}}{m_{i}}+\frac{\vec{F}_{i}^{\mathrm{G}}}{m_{i}}
\end{aligned}
$$

添字 $j$ は粒子 $i$ の近傍粒子を表し、 $u$ は速度、 $t$ は時刻、 $m$ は 粒子の質量、 $p$ は圧力、 $v$ は動粘度である。 $\rho$ は粒子の密度 であり、カーネル関数 $W$ を用いて $\rho_{i}=\Sigma_{j} m_{j} W_{i j}$ と表される。 $g$ は重力加速度、 $\vec{F}^{\mathrm{L}} 、 \vec{F}^{\mathrm{LS}}$ は粒子間凝集モデルによる表面張力 ベクトル、 $\vec{F}^{\mathrm{G}}$ はガス流から受ける下向きの抗力ベクトルで ある。式 (4) 右辺に执いて、各項は圧力勾配、粘性力、重 力、表面張力、ガス流から受ける下向きの抗力を示している。 また本計算では福西らの開発した非圧縮性近似手法 ${ }^{20)}$ を用 いている。この非圧縮性近似手法は式 (4) の圧力勾配項を 用いて流体内部の密度場を均一にするアルゴリズムであり、 その詳細や SPH 法の基礎原理については先行研究 ${ }^{21)}$ に記載 されている。

粒子間凝集モデルによる表面張力ベクトル $\vec{F}^{\mathrm{L}} 、 \vec{F}^{\mathrm{LS}}$ は先 行研究 ${ }^{22)}$ に従い、それぞれ次の 2 式で求めることができる。

$$
\begin{aligned}
& \vec{F}_{i}^{\mathrm{L}}=\left.1.2(1-\psi) \gamma d \sum_{j} f_{i j}^{\text {attract }}\right|_{i, j \in \text { Liquid }} \\
& \vec{F}_{i}^{\mathrm{LS}}=1.2 \psi \gamma d \sum_{j} f_{i j} \text { attract }\left.\right|_{i, j \in(\text { Liquid } \cup \text { Solid })}
\end{aligned}
$$

$\psi$ は濡れ角を決める定数であるが、本計算では固液間の結
びつきの度合いを決めるパラメータとして使用し、0.98 と 設定する。 $\gamma$ は表面張力係数、 $f_{i j}^{\text {attract }}$ は粒子間距離 $\left|\vec{r}_{i j}\right|$ によっ て決まる関数 ${ }^{22)}$ である。この関数は $\left|\vec{r}_{i j}\right|$ が粒子直径の 2 倍 以内の近傍粒子 $j$ との凝集力を考慮しており、| $\vec{r}_{i j} \mid$ が粒子直 径に等しいときにその影響が最大となる。これら表面張力 ベクトル $\vec{F}^{\mathrm{L}} 、 \vec{F}^{\mathrm{LS}}$ の添字 L、S は、それぞれの式を計算す る際に対象となる粒子の状態を示している。粒子 $i 、 j$ が共 に液体 (Liquid) の場合は式 (5) と式（6）の両方を計算し、 粒子 $i 、 j$ のどちらかが固体（Solid）の場合は、式（6）のみ を計算する。

Fig. 2 は切断方向に対して垂直方向の被切断材料断面の 模式図である。本計算では非切断時の予熱火炎の外観 ${ }^{23)}$ か ら、熱源は図中の赤線で示す短半径 $l_{r}$ 、長半径 $l_{z}$ の半楕円 体と仮定している。式 (4) の抗力 $\vec{F}^{\mathrm{G}}$ は図中の水色の熱源 幅に存在する溶融金属に対して与えており、鉛直下向きに 1 粒子当たり $1.57 \mathrm{mN}$ と設定している。これは溶融金属が $2 \times 10^{5} \mathrm{~m} / \mathrm{s}^{2}$ に相当する加速度をガス流から受けていること を定性的に模擬するパラメータであり、高速のガス流によ る影響を示している。

粒子の温度変化は次式のエネルギー輸送方程式から求め ることができる。

$$
\frac{D T_{i}}{D t}=\frac{\kappa}{C} \sum_{j} m_{j} \frac{T_{i}-T_{j}}{\rho_{i} \rho_{j}\left|\vec{r}_{i j}\right|^{2}} \vec{r}_{i j} \cdot \nabla_{i} W_{i j}-\frac{\varepsilon \alpha A}{C m_{i}}\left(T_{i}^{4}-T^{\mathrm{R}^{4}}\right)+\frac{Q_{i}}{C m_{i}}
$$

$T$ は温度、 $\kappa$ は熱伝導率、 $C$ は比熱、 $\varepsilon$ は放射率 $(0.8) 、 \alpha$ は Stefan-Boltzmann 定数、 $A$ は粒子の断面積、 $T^{\mathrm{R}}$ は環境温度 $(300 \mathrm{~K})$ である。 $Q$ は半楕円体の熱源の内部に存在する表 面粒子に生じる、酸化反応による加熱量を表している。式 （7）の右辺第 1 項は粒子間の熱伝導を表し、第 2 項以降は 金属表面の粒子に生じる熱生成速度（放射損失、酸化反応 による加熱)である。一方、本計算では切断溝全体におい てガス火炎による入熱よりも被切断材料自身に生じる酸化 反応による加熱の影響が大きいと考え、ガス火炎との熱伝 達は考慮していない。これはガス切断の熱源であるガス火 炎による入熱がプラズマ切断やレーザ切断の熱源であるプ

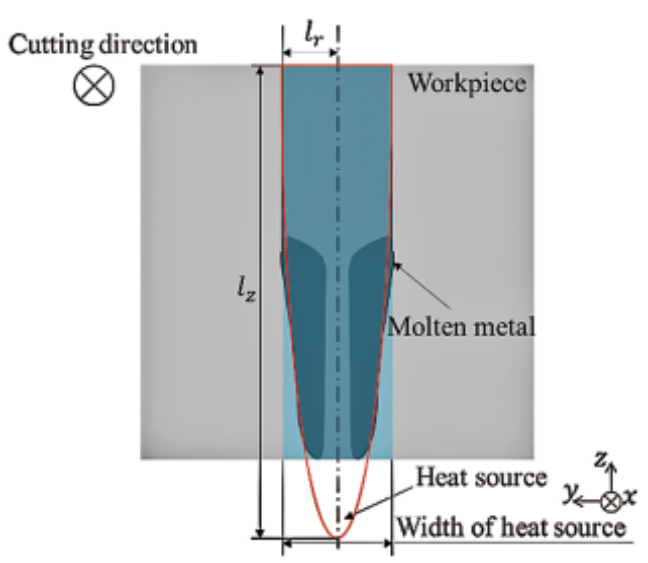

Fig. 2 Schematic illustration of heat source region. 
ラズマやレーザの入熱に比べて低いにも関わらず、酸化反 応が生じることで被切断材料を溶融させ、厚い鋼板を切断 できるという実験事実に基づいている。

続いて酸化反応による加熱のモデルについて説明する。 本計算モデルでは、被切断材料や溶融金属の表面の金属粒 子が半楕円体の熱源の内部に存在するとき、酸化が進行す る。時刻 $t$ において、熱源である半楕円体内の任意の位置 $\vec{r}_{i}=\left(x_{i}, y_{i}, z_{i}\right)$ に存在する被切断材料の表面粒子 $i$ の酸化速度 $f\left(\vec{r}_{i}\right)$ を式 (8)、式 (9) のようにモデル化する。

$$
\begin{gathered}
f\left(\vec{r}_{i}\right)=B\left(z_{i}\right) \exp \left(-\frac{\left|\overrightarrow{r_{i h}}\right|^{2}}{l_{r}^{2}}\right) \\
B\left(z_{i}\right)= \begin{cases}\frac{4 \chi}{9 l_{z}}\left[z_{i}-\left(z^{\mathrm{W}}-2.5 l_{z}\right)\right] & \left(z_{i}<z^{\mathrm{W}}-0.25 l_{z}\right) \\
\chi-\frac{4 \chi}{3 l_{z}}\left[z_{i}-\left(z^{\mathrm{W}}-0.25 l_{z}\right)\right] & \left(z^{\mathrm{W}}-0.25 l_{z} \leq z_{i}\right)\end{cases}
\end{gathered}
$$

$\left|\vec{r}_{i \mathrm{~h}}\right|$ は金属粒子 $i$ と熱源中心との $x y$ 平面上の距離を表す。 $B$ ( $z$ ) は任意の高さ $z$ における熱源中心軸の酸化速度であり、 $\chi$ は酸化速度のピーク值を決めるパラメー夕、 $z^{\mathrm{W}}$ は被切断 材料天面の $z$ 座標である。本計算では水素ガスを予熱ガス として用いた予熱炎と、LPG を用いた予熱炎を想定し、そ れぞれを水素ガス熱源、LPG 熱源と呼称する。先行研究で は実験により LPG と水素/LP の混合ガスの火炎の温度分布 を求めており、混合ガスを用いた火炎の方が LPGを用いた 火炎に比べて火炎中心の温度が高く、外側の温度がやや低 かった ${ }^{6)}$ 。このことから本研究では定性的なパラメータで ある $l_{r} 、 l_{z} 、 \chi$ を、水素ガス熱源の場合は $l_{r}=0.7 \mathrm{~mm} 、 l_{z}=6.0$ $\mathrm{mm} 、 \chi=60 、 \mathrm{LPG}$ 熱源の場合は $l_{r}=0.9 \mathrm{~mm} 、 l_{z}=6.0 \mathrm{~mm} 、 \chi$ $=30$ とそれぞれ設定する。これらの分布は、水素ガスを用 いたガス火炎は LPGを用いた場合に比べてガス火炎の外 側の温度が低いことで被切断材料の酸化範囲が狭く、また 中心部では温度が高いために酸化が促進されることを模擬 している。時刻 $t$ における金属表面の粒子 $i$ の酸化率 $\delta_{i}^{t}$ は $\delta_{i}^{t} \leqq 1$ の範囲内で次式から得られる。

$$
\delta_{i}^{t}=\int_{0}^{t} f(\vec{r}) d t
$$

以上に示した各時刻の酸化率の変化と式 (1) に基づく被 切断材料の燃焼熱 $Q^{\mathrm{O}}$ を用いて、酸化反応による加熱量 $Q$ は次式のように求められる。

$$
Q_{i}=\left(\delta_{i}^{t}-\delta_{i}^{t-\Delta t}\right) Q^{\mathrm{O}}
$$

\section{2 計算条件}

Fig. 3 に計算領域を示す。本計算では予熱による切断初 期の切断溝形成の時間を短縮するため、被切断材料には予 め切断溝を形成しており、1,200 Kに予熱された 169,000 個の粒子によって構成される。これらの粒子には軟鋼の物 性 ${ }^{14), 24-26)}$ の範囲内で、温度依存性を考慮しない一定の物 性值が与えられており、その融点は鉄の融点を設定してい る27)。また計算開始時点での計算領域内の全粒子の酸化率 $\delta$ は 0 とする。図中の一点鎖線は切断線であり、この線上
を熱源が切断速度で移動する。Table 2 に計算条件を示す。 切断速度は $150 \mathrm{~mm} / \mathrm{min}$ または $600 \mathrm{~mm} / \mathrm{min}$ と設定する。実 験で設定した $290 \mathrm{~mm} / \mathrm{min}$ ではなく $600 \mathrm{~mm} / \mathrm{min}$ と設定して いるのは、本計算では $150 \mathrm{~mm} / \mathrm{min}$ と $290 \mathrm{~mm} / \mathrm{min}$ で切断し た際に両者の計算結果に差が生じなかったためである。そ こで切断速度を増加させたところ、600 mm/min と設定した 際に両者の結果に差が生じたため、本計算では切断速度を $150 \mathrm{~mm} / \mathrm{min}$ と $600 \mathrm{~mm} / \mathrm{min}$ に設定して比較を行う。この実 験と計算での切断速度の違いは、計算において被切断材料 の寸法を実験よりも小さく設定したことによって、溶融金 属が切断溝を流れ落ちる距離が短くなっていることや、切 断溝を流れ落ちる溶融金属量が異なることによるものであ ると考えられる。このように最大の切断速度は実験と計算 で異なるものの、実験と計算で同様の傾向が得られている のであれば、切断速度の大小が溶融金属の流動現象に及ぼ す影響について定性的な議論をすることは可能である。

本研究では固体の速度を $0 \mathrm{~m} / \mathrm{s}$ と設定することで、被切 断材料や凝固後のドロスを表現している。相変化の際は潜 熱を考慮し、温度が融点に達した粒子の相変化はすぐに起 こらず、潜熱期間の中間点で生じるものとしている ${ }^{11), 15) 。 ~}$ したがって、ある時刻に温度が融点に達した固体粒子 $i$ は、

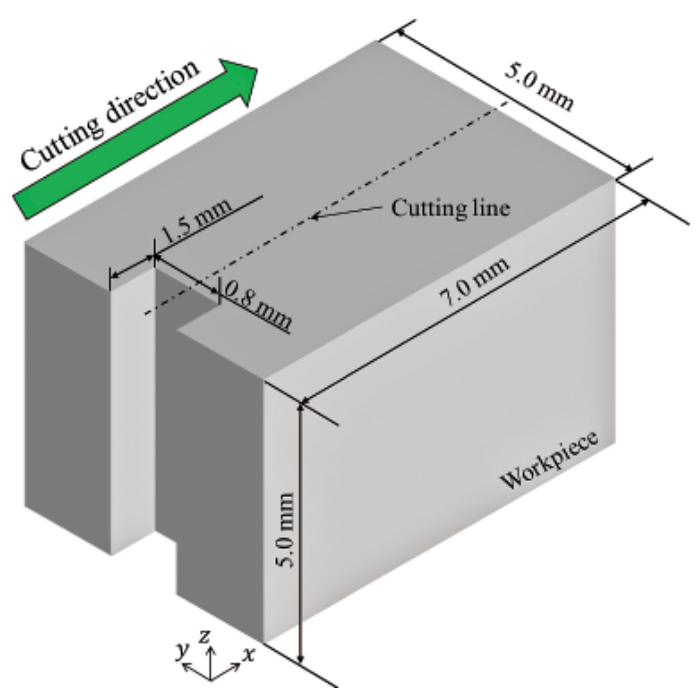

Fig. 3 Computational domain.

Table 2 Computational conditions.

\begin{tabular}{lr}
\hline Particle diameter $d$ & $0.1 \mathrm{~mm}$ \\
Time step $\Delta t$ & $1.0 \times 10^{-5} \mathrm{~s}$ \\
Cutting speed & $150,600 \mathrm{~mm} / \mathrm{min}$ \\
Melting point & $1,811 \mathrm{~K}$ \\
Density $\rho$ & $7.85 \times 10^{3} \mathrm{~kg} / \mathrm{m}^{3}$ \\
Kinematic viscosity $v$ & $5.0 \times 10^{-7} \mathrm{~m}^{2} / \mathrm{s}$ \\
Thermal conductivity $\kappa$ & $67 \mathrm{~W} / \mathrm{m} / \mathrm{K}$ \\
Specific heat $C$ & $460 \mathrm{~J} / \mathrm{kg} / \mathrm{K}$ \\
Surface tension coefficient $\gamma$ & $1.0 \mathrm{~N} / \mathrm{m}$ \\
Latent heat & $250 \mathrm{~kJ} / \mathrm{kg}$ \\
\hline
\end{tabular}


その時刻から時間ステップ $\Delta t$ あたりの温度の増加量 $\Delta T_{i}$ に 比熱 $C$ をかけたエンタルピーの増加量の総和が、潜熱の半 分を超えた時点で液体に相変化する。同様に、ある時刻に 温度が融点に達した液体粒子は、その時刻からのエンタル ピーの減少量の総和が潜熱の半分を超えた時点で固体へと 相変化する。なお潜熱期間中の粒子もエンタルピー算出の ため温度の変化量が計算されるが、その温度は融点に固定 される。また金属表面で酸化反応は生じるものの、金属内 部への酸素原子の拡散は考慮していない。

\section{4. 結果および考察}

4.1 予熱ガスがドロスの形成過程や剥離性に及ぼす影響

はじめに異なる予熱ガスを用いて切断速度 $150 \mathrm{~mm} / \mathrm{min}$ で切断し、予熱ガスの違いが被切断材料暠面の溶融金属の 流動に与える影響を調査した。Fig. 4 に予熱ガスにLPGを 用いて切断した際の、被切断材料裏面の実験観察結果を示 す。図中の各時刻は、Fig. 4 (a) を基準とした相対時刻を 示している。切断溝から流れ出た溶融金属は図中の水色の 矢印で示すように、切断方向後方に流れ、液柱を形成しな がら垂れ落ちた（Fig. 4 (a))。新たに切断溝から流れ出た 溶融金属もごく一部は切断方向前方に飛散するものの、多 くは被切断材料裏面に付着し、その後に切断方向後方で 液滴や液柱を形成しながら流れ落ちていった（Figs. 4 (b)(d))。切断後のドロスは、容易ではなかったもののケレン を用いて剥離することが可能であった。Fig. 5 に予熱ガス に水素ガスを用いた際の、被切断材料裏面の観察結果を示 す。この図もFig. 4 と同様に、図中の各時刻はFig. 5 (a) を基準とした相対時刻を示している。予熱ガスに LPGを用 いた場合と異なり、水素ガスを用いた場合では溶融金属は 切断方向後方には流れず、切断溝前縁部近傍にとどまった (Fig. $5(\mathrm{a}))$ 。そして新たに流れ落ちてきた溶融金属も後方 には流れず液滴となって流れ落ちるか、Fig. 5 (a) 中の水 色の矢印で示すように、液柱を形成した後にその先端が離

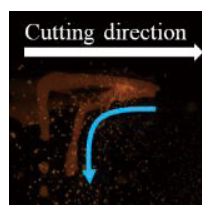

(a) $t=0.0 \mathrm{~ms}$

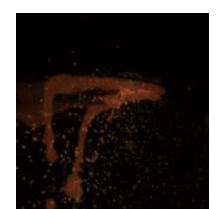

(b) $t=20.0 \mathrm{~ms}$

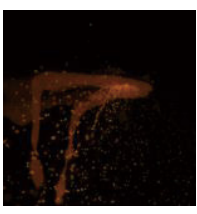

(c) $t=43.0 \mathrm{~ms}$

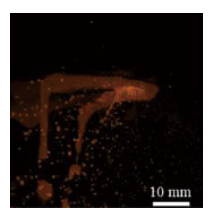

(d) $t=53.0 \mathrm{~ms}$
Fig. 4 Dross behavior on underside of workpiece (preheating gas: LPG, cutting speed: $150 \mathrm{~mm} / \mathrm{min}$ ).

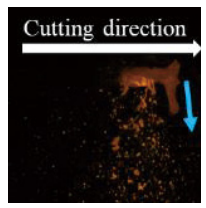

(a) $t=0.0 \mathrm{~ms}$

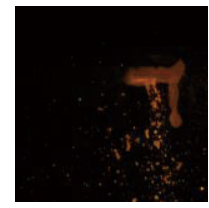

(b) $t=18.5 \mathrm{~ms}$

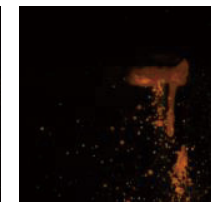

(c) $t=46.5 \mathrm{~ms}$

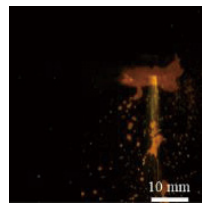

(d) $t=83.0 \mathrm{~ms}$
Fig. 5 Dross behavior on underside of workpiece (preheating gas: hydrogen gas, cutting speed: $150 \mathrm{~mm} / \mathrm{min}$ ).
脱して流れ落ちた (Figs. 5 (a)-(d))。切断後のドロスの大 部分は剥離しており、ケレンを使用せず容易に剥離するこ とが可能であった。このように異なる予熱ガスを用いるこ とで、切断中の被切断材料の溶融状況に違いが生じた。ま た切断後のドロスの剥離性も異なり、水素ガスを予熱ガス に用いた方がドロスの剥離が容易であった。

同様に切断速度を $150 \mathrm{~mm} / \mathrm{min}$ と設定し、異なる熱源分 布を用いた際のドロスの形成過程をシミュレートした結果 を示す。Fig. 6 は LPG 熱源を用いた際の、各時刻におけ る溶融金属の温度分布である。図は切断線に沿った縦断面 であり、水色の一点鎖線は各時刻における熱源の中心軸を 示している。濃い灰色の粒子は未溶融の被切断材料を、薄 い灰色の粒子は再凝固したドロスを表しており、溶融金属 は自身の温度によって青から赤で色づけられている。計算 開始時は、熱源の範囲内に存在する被切断材料表面は自身 の酸化反応によって温度が上昇して溶融し、多量の溶融金 属が生じる。この溶融金属は切断溝を流れ落ちた後、被切 断材料裏面に付着する(Fig. $6(\mathrm{a}))$ 。切断溝上方で新たに 形成された溶融金属のうち、切断溝の側面を流れるものは ドロスを伝うように流れた後、ドロス先端部で凝固するこ とでドロスを成長させる (Fig. 6 (b))。一方、切断溝前方 を流れ落ちてくる溶融金属はドロスを伝うように熱源後方 へと流れるか、切断溝前縁部から流れ落ちる（Figs. 6 (c)， (d))。その後も熱源後方へと流れる溶融金属によるドロス の成長と、切断溝前方を流れ落ちる溶融金属の飛散が生じ ながら切断が進行する（Figs. 6 (e)，(f)）。実験と比較して、 本計算では溶融金属は熱源中心近傍で凝固し、切断溝後方 へと流れる溶融金属の量が少ない。これは実験よりも熱源 や被切断材料の寸法を縮小したことで、被切断材料董面へ と流れる溶融金属の量が少なくなり、冷却されやすいため であると考えられる。

Fig. 7 に水素ガス熱源を用いた際の各時刻における溶融 金属の温度分布を示す。図は切断線に沿った縦断面であり、

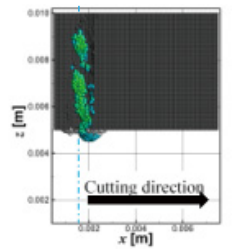

(a) $t=13.0 \mathrm{~ms}$

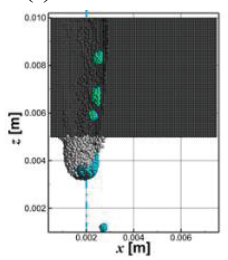

(d) $t=163.0 \mathrm{~ms}$

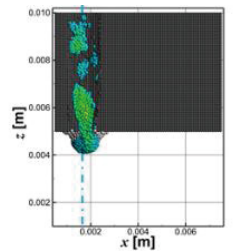

(b) $t=27.0 \mathrm{~ms}$

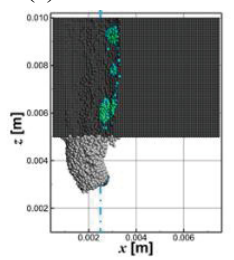

(e) $t=340.0 \mathrm{~ms}$

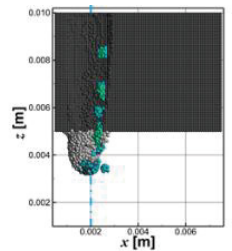

(c) $t=162.0 \mathrm{~ms}$

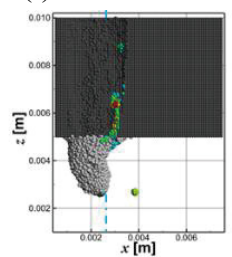

(f) $t=400.0 \mathrm{~ms}$
18111900200021002200230024002500

Fig. 6 Temperature distribution of molten metal (heat source: LPG, cutting speed: $150 \mathrm{~mm} / \mathrm{min}$ ). 
水色の一点鎖線は各時刻における熱源の中心軸を示してい る。また粒子はFig. 6 と同様に色づけられている。図より、 切断溝側面は自身の酸化反応によって温度が上昇して溶融 し、溶融金属は切断溝を伝いながら被切断材料下部へと流 れる (Fig. $7(\mathrm{a})$ )。この溶融金属に注目すると、水素ガス 熱源は LPG 熱源よりも緊縮しているため、熱源内の被切 断材料の酸化が促進されることで流れ落ちる溶融金属がよ り高温になる(Fig. 7 (b))。切断溝側面を流れ、底部へと 到達した多くの溶融金属は熱源中心より前方へ流れ落ちる が、一部の溶融金属は被切断材料裏面に流れ込んだ後冷却 されて再凝固しドロスとなる (Figs. 7 (b)-(d))。一方、切 断溝前縁部から流れ落ちる溶融金属は切断方向前方へと飛 散する (Figs. 7 (d)-(f))。この計算結果およびFig. 5 に示 した実験結果を用いて Weber 数We を比較することで、実 際よりも縮小された被切断材料や熱源を用いた本計算の妥 当性を評価した。ここでWeber 数とは流体の慣性力と表面 張力の比を表す無次元数であり、次式で表される ${ }^{28)}$ 。

$$
W e=\frac{\rho L u^{2}}{\gamma}
$$

$L$ は代表長さであり、本研究では被切断材料毫面に付着し た溶融金属の厚みとした。実験のWeを算出する際は、被 切断材料裏面に付着した溶融金属表面を流れるスラグの、 1 フレームあたりの変位から平均の速度を算出した。また Fig. 5 (d) から被切断材料裏面に付着した溶融金属の平均 の厚みを測定し、密度と表面張力係数については純鉄の物 性值 ${ }^{27)}$ を用いた。計算結果においては Table 2 に示した 密度と表面張力係数を使用し、Fig. 7 (f) に示した結果か ら被切断材料裏面に付着した溶融金属の速度と厚みの平 均值を得た。その結果、Fig. 5 に示した実験結果のWeが 11.8 であったのに対し、Fig. 7 に示した計算結果のWeは 14.8 であり、実現象とよく一致するWeber 数が得られた。 このことから本計算は実験と相似則が成り立っており、定 性的ではあるものの実現象と同等な現象がシミュレートで

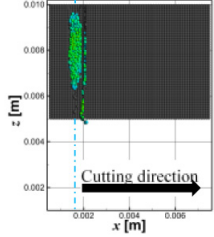

(a) $t=3.0 \mathrm{~ms}$

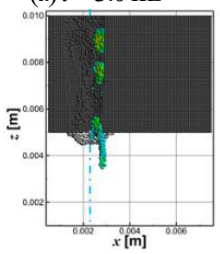

(d) $t=261.0 \mathrm{~ms}$

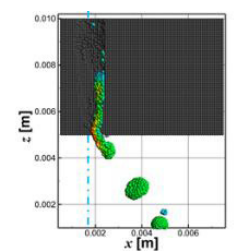

(b) $t=42.0 \mathrm{~ms}$

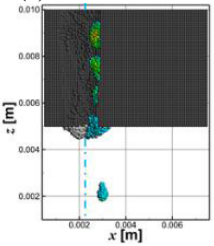

(e) $t=262.0 \mathrm{~ms}$
$T[\mathbf{K}]$

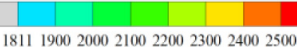

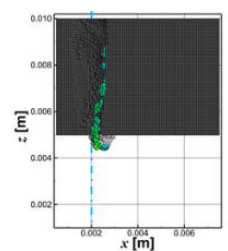
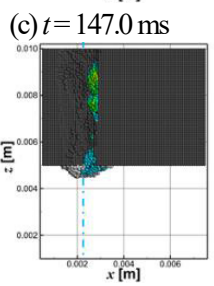

(f) $t=263.0 \mathrm{~ms}$
Fig. 7 Temperature distribution of molten metal (heat source: hydrogen gas, cutting speed: $150 \mathrm{~mm} / \mathrm{min}$ ).
きているといえる。

本計算で見られた予熱ガスによる流動の違いは、それぞ れの熱源によって酸化速度が異なることによると考えられ

る。Fig. 8 および Fig. 9 に計算開始から $500 \mathrm{~ms}$ 後の、切 断線上の被切断材料のスライス面を示す。両者を比べると LPG 熱源を用いて切断を行った方が切断溝の傾斜がやや緩 やかであることがわかる。これは LPG 熱源の方が水素熱 源に比べて半径方向の酸化範囲が広く、中心部の酸化速度 が小さいためである。この違いによって被切断材料上部が 下部よりも先行して溶融することで切断溝の溶融状況に差 が生じ、切断溝の傾斜が緩やかになる。そして溶融金属は この切断溝を伝って流れ落ちてくるため、被切断材料裏面 に到達した溶融金属は切断方向後方へと流れると考えられ る。一方、水素ガス熱源は LPG 熱源に比べて半径方向の酸 化範囲は狭く、中心部の酸化速度が大きいため被切断材料 上部と下部の溶融量の差が小さくなる。そのため切断溝の 傾斜は急になり、切断溝を伝った溶融金属は下方や切断方 向前方に向かって流れ落ちると考えられる。

Fig. 10 に切断線に沿った被切断材料の断面の模式図を示 す。図中に赤線で示す被切断材料 - ドロス界面を図の赤色 の矢印の方向から観察することで、被切断材料に接するド ロスの酸化率を調査した。Fig. 11 に計算開始から $500 \mathrm{~ms}$ 後の、ドロスの被切断材料との固着面の外観を示す。粒子 の色はその粒子の酸化率を示しており、水色の円は熱源の 中心位置を示している。Fig. 11 (a) に示した固着面のドロ スの平均の酸化率は $16.1 \%$ であり、Fig. 11 (b) の固着面の ドロスの平均の酸化率は $28.3 \%$ である。外観や平均の酸化

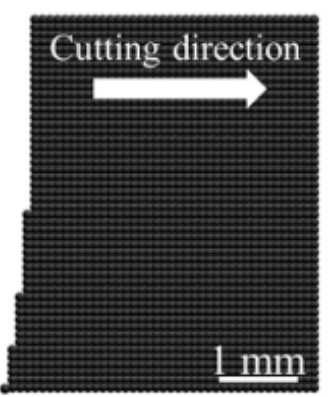

Fig. 8 Cutting groove shape along cutting line (heat source: LPG, cutting speed: $150 \mathrm{~mm} / \mathrm{min}$ ).

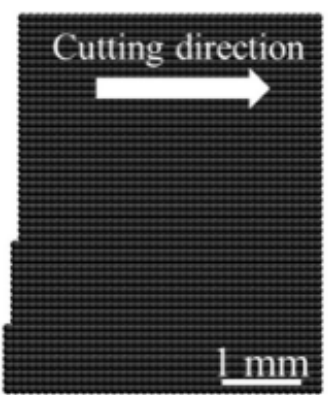

Fig. 9 Cutting groove shape along cutting line (heat source: hydrogen gas, cutting speed: $150 \mathrm{~mm} / \mathrm{min}$ ). 
率から、同じ切断速度で熱源を動かした場合は水素ガス熱 源の方がドロス表面が酸化していることがわかる。これは LPG 熱源よりも水素ガス熱源の方が酸化範囲が狭く、熱源 中心部の酸化速度が大きいためである。これにより溶融金 属は切断溝を流れ落ちる過程で強く酸化し、被切断材料裏 面に付着して凝固することで固着面の酸化率は高くなる。 一方 LPG 熱源の場合、酸化範囲は水素ガス熱源よりも広が り、中心部の酸化速度は小さい。そのため切断溝を流れ落 ちる過程で溶融金属は緩やかに酸化が進行し、ドロスの被 切断材料への固着面はあまり酸化していなかったと考えら れる。この結果は、実験から得られたドロスの剥離性と関 連していると考えられる。すなわち、ドロスが酸化してい ない場合は被切断材料裏面に付着した溶融金属が裏面と強 く接合され、切断後のドロスの剥離が困難になる。一方、 ドロスが酸化している場合、被切断材料裏面とドロスの間 に酸化膜が巻き込まれることで接合部の強度が低下し、ド ロスが容易に剥離できたと考えられる。

\section{2 切断速度がドロスの形成過程や剥離性に及ぼす影響}

予熱ガスとして、先行研究 ${ }^{7)}$ によって高速で切断可能で あることが報告された水素ガスを使用し、異なる切断速度 を設定することで切断速度が被切断材料亭面の溶融金属の 流動に与える影響を調査した。Fig. 12 に示すのは、切断速 度を $290 \mathrm{~mm} / \mathrm{min}$ と設定して切断した際の被切断材料裏面 の実験観察結果である。図中の各時刻は Fig. 12 (a) を基準

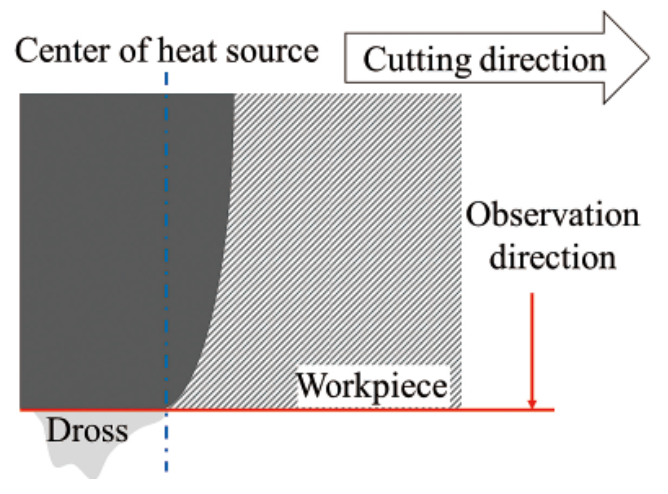

Fig. 10 Schematic illustration of observation face.

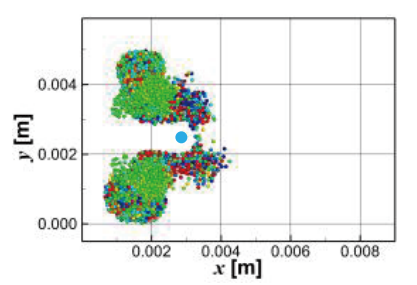

(a) LPG heat source

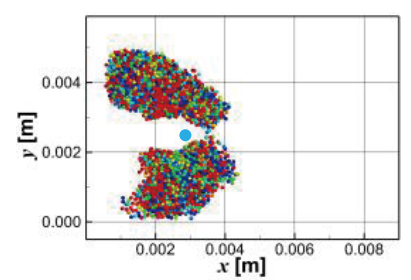

(b) Hydrogen gas heat source

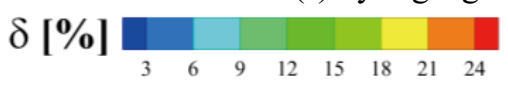

Fig. 11 Dross appearance for each computational condition (cutting speed: $150 \mathrm{~mm} / \mathrm{min}$ ).
とした相対時刻である。予熱ガスに水素ガスを使用して切 断速度 $150 \mathrm{~mm} / \mathrm{min}$ で切断した場合と同様に、溶融金属は 切断溝前縁部にとどまる。そして切断方向前方では溶融金 属が液柱や液滴を形成しながら、図中の水色の矢印で示す ように、流れ落ちる一連の過程が継続的に生じていた（Figs. $12(\mathrm{a})-(\mathrm{d}))$ 。切断後のドロスはケレンを使用する必要があっ たものの、ほとんど力を入れることなく剥離が可能であっ た。

同様に水素ガス熱源を用い、異なる切断速度を設定した 際の切断過程をシミュレートした。Fig. 13 に示すのは切断 速度を $600 \mathrm{~mm} / \mathrm{min} に$ 設定しシミュレーションを行った際 の、各時刻における切断線に沿った縦断面の温度分布であ る。粒子の色は Fig. 7 と同様に色づけられており、水色の 一点鎖線は各時刻における熱源の中心軸を示している。式 （8）で示したように、本研究で設定した酸化速度は各 $z$ 座 標において、熱源の中心が最も大きくなっている。そのた め切断速度が大きくなった場合、熱源が速く移動すること で切断溝前縁の酸化速度が増加する。これにより被切断材 料の加熱量が増加し、被切断材料底部から離脱して流れ落 ちる溶融金属の温度は、 $150 \mathrm{~mm} / \mathrm{min}$ で切断した Fig. 6 や Fig. 7 のときよりも高くなる (Figs. 13 (a)-(c))。また水素

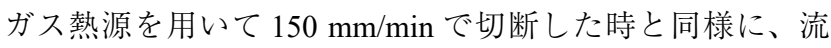
れ落ちる溶融金属は下方や熱源中心より前方へ流れ落ちて おり、実験と同様の傾向が得られている。そして、一部の

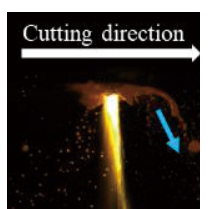

(a) $t=0.0 \mathrm{~ms}$

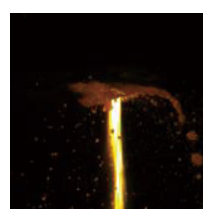

(b) $t=45.5 \mathrm{~ms}$

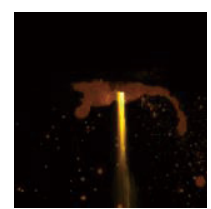

(c) $t=137.0 \mathrm{~ms}$

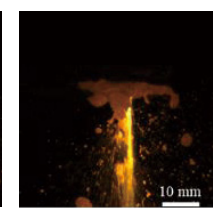

(d) $t=217.0 \mathrm{~ms}$
Fig. 12 Dross behavior on underside of workpiece (preheating gas: hydrogen gas, cutting speed: $290 \mathrm{~mm} / \mathrm{min}$ ).

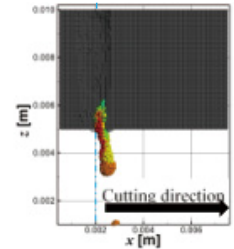

(a) $t=37.0 \mathrm{~ms}$

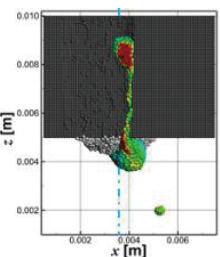

(d) $t=192.0 \mathrm{~ms}$

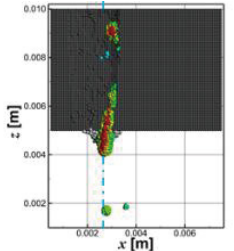

(b) $t=102.0 \mathrm{~ms}$

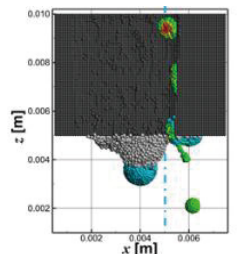

(e) $t=330.0 \mathrm{~ms}$

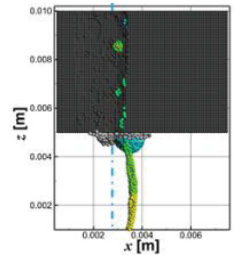

(c) $t=113.0 \mathrm{~ms}$

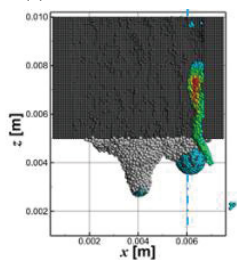

(f) $t=443.0 \mathrm{~ms}$

\section{$\boldsymbol{T}[\mathbf{K}]$}

18111900200021002200230024002500

Fig. 13 Temperature distribution of molten metal (heat source: hydrogen gas, cutting speed: $600 \mathrm{~mm} / \mathrm{min}$ ). 


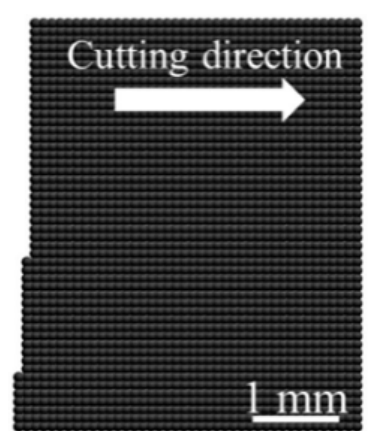

Fig. 14 Cutting groove shape along cutting line (heat source: hydrogen gas, cutting speed: $600 \mathrm{~mm} / \mathrm{min}$ ).

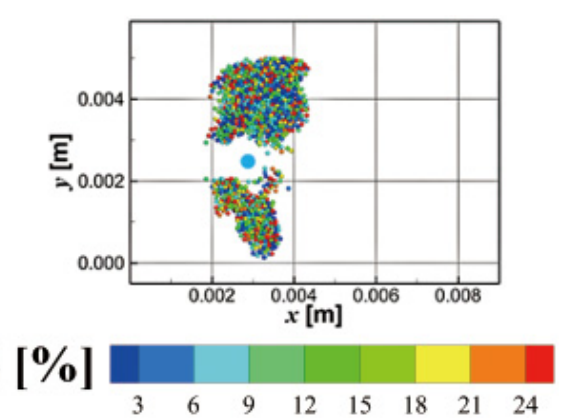

Fig. 15 Dross appearance (heat source: hydrogen gas, cutting speed: $600 \mathrm{~mm} / \mathrm{min}$ ).

溶融金属は被切断材料裏面に流れ込んだ後、再凝固するこ とでドロスとなる (Figs. 13 (d)-(f))。Fig. 14 に示すのは 切断線上の被切断材料のスライス面である。Fig. 9 と同じ 距離の切断を行った位置で比較するため、図は計算開始か ら $125 \mathrm{~ms}$ 後の計算結果を示している。Fig. 14 より、Fig. 9 と同様に切断溝の勾配は急であることがわかる。このよう に切断溝前縁部の勾配が急になることで、溶融金属は切断 溝内で後方へと流れる慣性力が得られず、下方や切断溝前 方に流れ落ちたと考えられる。

Fig. 15 に被切断材料に接触しているドロスの固着面の外 観を示す。Fig. 11 と同様に粒子の色はその粒子の酸化率を 示して抢り、水色の円は熱源の中心位置を示している。こ の図は Fig. 11 (b) と同じ距離の切断を行った際のドロスを 比較するため、計算開始から $125 \mathrm{~ms}$ 後の計算結果を示し ている。このドロス表面の平均酸化率は $14.1 \%$ である。こ の值や外観を Fig. 11 (b) と比べると、同じ水素ガス熱源を 用いた場合でも切断速度が大きくなることで、被切断材料 に接触しているドロス表面の酸化率は低下寸ることがわか る。これはドロスが主に切断溝側面を流れ落ちた溶融金属 によって構成されているためである。熱源が大きい速度で 移動することによって、切断溝側面を流れ落ちる溶融金属 は十分に酸化する前に熱源の範囲から外れる。その結果、 溶融金属は $150 \mathrm{~mm} / \mathrm{min}$ で切断した場合ほど酸化すること なくドロスとなって被切断材料裏面に固着し、ドロスの剥 離性が悪くなったと考えられる。

\section{5. 結 言}

本研究では切断速度やガス種の違いが被切断材料裏面に おけるドロスの形成やその剥離性に及ぼす影響について明 らかにすることを目的とし、まずは高速度ビデオカメラを 用いた実験観察を行うことで切断速度やガス種の違いによ る溶融金属の流動を調査すると共に、切断後にドロスを剥 離することでその剥離性の違いを定性的に評価した。また 粒子法の 1 種である非圧縮性 SPH 法を用いて、ガス切断中 の被切断材料の溶融現象や流動現象のモデル化を試みた。 そして構築した計算モデルによって、実験観察が困難な切 断溝内の溶融金属の流動現象をシミュレートした。本研究 で得られた知見を以下に示す。

（1）予熱ガスに LPGを用いて $150 \mathrm{~mm} / \mathrm{min} て ゙$ 切断した場合、 切断溝から流れ出た溶融金属は切断方向後方に流れ、 液柱を形成しながら垂れ落ちた。一方、予熱ガスに水 素ガスを用いて $150 \mathrm{~mm} / \mathrm{min} て ゙$ 切断した場合、溶融金属 は切断方向後方には流れず、切断溝前縁部近傍にとど まった。そして新たに流れ落ちてきた溶融金属も後方 には流れず、液滴となって流れ落ちるか、液柱を形成 した後にその先端が離脱して流れ落ちた。また切断後 のドロスの剥離性も異なり、水素ガスを予熱ガスに用 いた方がドロスの剥離が容易であった。

（2）切断速度が $150 \mathrm{~mm} / \mathrm{min}$ と設定した場合、熱源によって 切断溝の形状が異なるため、溶融金属の流動に差が生 じることが数值計算結果から示唆された。また水素ガ スの予熱炎を想定した熱源を用いた場合の方が LPGの 予熱炎を想定した熱源を用いた場合よりもドロスの被 切断材料裏面への固着面は酸化した。この結果から、 被切断材料暠面とドロスの間に酸化膜が巻き込まれる ことで接合部の強度が低下し、水素ガスを予熱ガスに 用いた方がドロスを容易に剥離できたと示唆された。

（3）予熱ガスに水素ガスを用いた場合、切断速度が大きく なっても溶融金属の流動に差はなかった。これは数值 計算でも同様の傾向であり、溶融金属は切断溝前縁部 にとどまり、切断方向前方では溶融金属が液柱や液滴 を形成しながら流れ落ちる一連の過程が継続的に生じ ていた。また同じ水素ガス熱源を用いた場合でも、切 断速度が大きくなると被切断材料に接触しているドロ ス表面の酸化率は低下した。そのためドロスは被切断 材料裏面に強く固着し、ドロスの剥離性が悪くなった ことが示唆された。

\section{参考文献}

1）溶接学会 -日本溶接協会編: “溶接·接合技術総論”, 産報出版, (2016).

2）藤井俊英: “切断技術の実際（1）ガス切断”, 溶接学会誌, 61-8 (1992), 644-649.

3）水津寛一, 安田武夫: “ガス切断に関する二, 三の実験 (第 1 報) 一数種の市販火口の切断効率について-”, 溶接学会誌, 29-2 
(1960), 133-139.

4）水津寛一, 安田武夫: “ガス切断に関する二, 三の実験 (2) - 切 断効率におよぼす鋼温度の影響 -”, 溶接学会誌, 29-6 (1960), 490-497.

5）寺崎俊夫, 北村貴典, 宮本昌寬, 藤井俊英: “ガス切断により板 に与えられる熱量について”, 日本船舶海洋工学会論文集, 10 (2009), 197-204.

6）大沢直樹, 澤村淳司, 池上祐一, 山口和恵: “酸素ガス切断におけ る予熱ガス炎性状と切断性能の関係に関する研究”, 溶接学会 論文集, 31-2 (2013), 141-156.

7）谷口桂一: “水素ガス切断システム”, KOMATSU TECHNICAL REPORT, 50-154 (2004),15-18.

8）今村雅紀, 溝㴊啓, 谷本遼太朗, 佐久間淳: “スラグペーストによ る鋼板のガス切断におけるスラグ抑制メカニクス”, 設計工学, 55-1 (2020), 33-42.

9) B. S. Yilbas and B. J. A. Aleem: "Dross formation during laser cutting process", Journal of Physics D: Applied Physics, 39-7 (2006), 1451-1461.

10) V. A. Nemchinsky: "Dross formation and heat transfer during plasma arc cutting", Journal of Physics D: Applied Physics, 30-18 (1997), 2566-2572.

11）伊藤真澄, 伊澤精一郎, 福西祐, 茂田正哉: “非圧縮性 SPH法を用 いた TIG溶接における溶融池形成シミュレーション”, 溶接学 会論文集, 32-4 (2014), 213-222.

12) M. Ito, Y. Nishio, S. Izawa, Y. Fukunishi and M. Shigeta: "Numerical Simulation of Joining Process in a TIG Welding System Using Incompressible SPH Method", Quarterly Journal of the Japan Welding Society, 33-2 (2015), 34s-38s.

13) H. Komen, M. Shigeta and M. Tanaka: "Numerical Simulation of Molten Metal Droplet Behavior in Gas Metal Arc Welding by ThreeDimensional Incompressible Smoothed Particle Hydrodynamics Method", Journal of Flow Control, Measurement \& Visualization, 6-2 (2018), 66-81.

14）古免久弥, 茂田正哉, 田中学, 福西祐: “GMA 溶接における溶滴 輸送を伴う溶融池対流の非圧縮性SPHシミュレーション”, 溶 接学会論文集, 33-4 (2015), 332-340.

15) H. Komen, M. Shigeta and M. Tanaka: "Numerical simulation of molten metal droplet transfer and weld pool convection during gas metal arc welding using incompressible smoothed particle hydrodynamics method", International Journal of Heat and Mass
Transfer, 121 (2018), 978-985.

16) H. Komen, M. Shigeta, M. Tanaka, M. Nakatani and Y. Abe: "Simulation of Flux Melting Process during a SAW by DEM-ISPH Hybrid Method", Quarterly Journal of the Japan Welding Society, 35-2 (2017), 38s-41s.

17) H. Komen, M. Shigeta, M. Tanaka, M. Nakatani and Y. Abe: "Numerical simulation of slag forming process during submerged arc welding using DEM-ISPH hybrid method", Welding in the World, 62-6 (2018), 1323-1330.

18）茂田正哉: “アーク溶接における溶融金属流動の粒子法シミュ レーション”, 溶接学会誌, 86-6 (2017), 14-20.

19）茂田正哉, 田中学: “アーク溶接現象解明に向けた最先端診断・ 数值熱流体解析”, 電気学会誌 140-6 (2020), 350-353.

20) N. Okachi, A. Hirota, S. Izawa and Y. Fukunishi: "SPH simulation of pulsating pipe flow at a junction", Proceedings of the 1 st International Symposium on Advanced Fluid Information, (2001), 388-391.

21) M. Shigeta T. Watanabe, S. Izawa and Y. Fukunishi: "Incompressible SPH simulation of double-diffusive convection phenomena", International Journal of Emerging Multidisciplinary Fluid Sciences, 1-1 (2009), 1-18.

22）伊藤真澄: “非圧縮性SPH法を用いたアーク溶接プロセス中 流動現象の数值シミュレーション”, 東北大学博士学位論文, (2015).

23）上木原洋丘, 加藤隆: “水素を用いた溶断技術”, 溶接学会誌, 85-4 (2016), 341-345.

24）辻村吉寬: “ガスメタルアーク溶接における金属蒸気を伴う アーク現象とその熱源特性に関する研究”, 大阪大学博士学位 論文, (2012).

25）門田圭二: “GMA溶接における溶滴移行現象のモデル解析”, 大 阪大学博士学位論文, (2011).

26) Y. Ogino, Y. Hirata and S. Asai: "Numerical simulation of metal transfer in pulsed-MIG welding", Welding in the World, 61-6 (2017), 1289-1296.

27）国立天文台編: “理科年表 2019”, 丸善出版株式会社, (2019).

28）島章, 小林陵二: “水力学”, 丸善株式会社, (1980).

\section{代表者メールアドレス}

古免久弥 h.komen@jwri.osaka-u.ac.jp 